\title{
Analisis Pengaruh Hambatan Samping Terhadap Kinerja Ruas Jalan Veteran Selatan
}

\author{
Indrian Citra ${ }^{\star 1}$, Rais Rachman ${ }^{\star 2}$, Monika D.M Palinggi *3 \\ *1 Mahasiswa Prodi Teknik Sipil, Universitas Kristen Indonesia Paulus Makassar, Indonesia \\ indriancitra217@gmal.com \\ *2,3 Dosen Prodi Teknik Sipil, Universitas Kristen Indonesia Paulus Makassar, Indonesia \\ rais.rachman@gmail.com dan monikadatumirring@gmail.com
}

\begin{abstract}
ABSTRAK
Hambatan samping adalah aktivitas di samping jalan yang sangat menganggu kelancaran arus lalu lintas. Jalan yang seharusnya digunakan untuk arus lalu lintas tersita untuk kendaraan berhenti. Serta banyaknya akses keluar masuk kendar aan dari lahan sepanjang jalan semakin menambah kepadatan pada ruas jalan tersebut. Seharusnya ruas jalan yang dibutuhkan harus sesuai dengan ruas yang ada tanpa terganggu oleh hambatan samping. Faktanya ruas jalan Veteran Selatan ini cukup padat pada waktu tertentu dengan parkir kendaraan dan angkutan umum yang menurunkan penumpang di sepanjang jalan. Selain itu di tambah jumlah pejalan kaki yang berjalan atau menyebrang sepan jang segmen jalan, dan jumlah kendaraan bermotor yang masuk keluar dari samping jalan serta arus kendraan yang bergerak lambat. Penelitian ini bertujuan untuk mengteahui apakah hambatan samping adalah penyebab kemacetan pada ruas jalan Veteran Selatan, atau arus yang dating ke ruas jalan perintis kemerdekaan yang besar. Dari hasil analisis data diperoleh arus lalu lintas puncak rata-rata selama 3 hari pengamatan sebesar 1.606,6 smp/jam, hambatan samping pada saat arus puncak sebesar 283,7 smp/15 mnt kapasitas jalan sebesar 1474,4 smp/jam, derajat kejenuhan rata-rata sebesar 1,08.
\end{abstract}

Kata kunci : Hambatan Samping, ruas jalan perkotaan

\begin{abstract}
Side barriers are activities next to the road that disrupt the smooth flow of traffic. The path should be used for the unseized traffic flow for the vehicle to stop. As well as many outbound access to the vehicles from the land all the way increases the density of the road. The required road segments should correspond to the existing segments without being interrupted by side barriers. In fact, this road is solid enough at a certain time with a car park and public transportation that lowers passengers along the way. In addition, the number of pedestrians is running or crossing the road segments, and the number of motorised vehicles coming out of the side of the road and slow-moving currents. The research aims to provide a side barrier to whether the traffic is the cause of congestion on South veterans ' roads, or the current dating to the major Independence Pioneer Road section. From the results of data analysis obtained average peak traffic flow during 3 days observation of 1,606.6 SMP/hr, side barriers at the peak current of $283.7 \mathrm{SMP} / 15$ minutes of road capacity of 1474.4 $\mathrm{SMP} / \mathrm{hr}$, average degree of saturation of 1.08 .
\end{abstract}

Keywords: side barriers, urban road sections

\section{PENDAHULUAN}

Hambatan samping merupakan aktivitas samping jalan yang sering menimbulkan pengaruh yang cukup signifikan. Tingginya aktivitas samping jalan berpengaruh besar terhadap kapasitas dan kinerja jalan pada suatu wilayah perkotaan [1]. Diantaranya seperti pejalan kaki, penyebrang jalan, PKL (pedagang kaki lima), kendaraan bergerak lambat (becak, sepeda, kereta kuda), kendaraan berhenti sembarangan (angkutan kota, bus dalam kota), parker dibahu jalan (on street parking), dan kendaraan keluar-masuk pada aktivitas guna lahan sisi jalan.
Menurut Manual Kapasitas Jalan Indonesia (MKJI) 1997, hambatan samping adalah dampak terhadap kinerja lalu lintas dari aktivitas samping segmen jalan, seperti pejalan kaki, kendaraan yang berhenti dan parkir, kendaraan yang bergerak lambat, kendaraan yang keluar masuk di samping jalan [2]. Pejalan kaki adalah istilah dalam trasnsportasi yang digunakan untuk menjelaskan orang yang berjalan di lintasan pejalan kaki, baik di pinggir jalan atau lintasan khusus bagi pejalan kaki ataupun menyebrang jalan. Untuk melindungi pejalan kaki dalam berlalu lintas, pejalan kaki wajib berjalan pada bagianjalan dan menyebrang pada 
tempat pemyebrangan yang telah disediakan bagi pejalan kaki. Parkir adalah keadaan tidak bergerak suatu kendaraan yang bersifat sementara sedang berhenti atau keadaan tidak bergeraknya suatu kendaraan untuk sementara dengan pengemudi tidak meninggalkan kendaraannya [3]. Parkir merupakan suatu kebutuhan bagi pemilik kendaraan dan menginginkan kendaraannya parkir di tempat, dimana ditempat mudah untuk dicapai [4]. Kemudahan yang diinginkan tersebut salah satunya adalah parkir di badan jalan. Penyediaan tempat-tempat parkir di pinggir jalan pada lokasi tertentu baik di badan jalan maupun dengan menggunakan sebagian dari perkerasan jalan, mengakibatkan turunnya kapasitas jalan, terhambatnya arus lalu lintas dan penggunaan jalan menjadi tidak efektif [5]. Kendaraan yang Bergerak Lambat salah satu faktor yang menyebabkan hambatan samping yaitu kendaraan yang bergerak lambat, sehingga menyebabkan arus lalu lintas menjadi tidak maksimal [6]. Kegiatan-kegiatan yang dilakukan di pinggir jalan dapat mempengaruhi aktivitas jalan. Salah satu adalah kendaraan yang keluar masuk disamping jalan.Hal ini menyebabkan timbulnya hambatan samping yang terjadi akibat banyaknya kegiatan pada jalan tersebut.Dan menurut MKJI 1997 untuk survei hambatan samping ditetapkan jarak $200 \mathrm{~m}$ [2].

Beberapa peneliti yang telah meneliti masalah hambatan samping pada ruas jalan antara lain Pirade at.al (2019) yang meneliti tentang Pengaruh Hambatan Samping Terhadap Kinerja Ruas Jalan Antang Raya Kota Makassar [3]. Kurniawan (2016) meneliti tentang Analisa Hambatan Samping Terhadap Tingkat Pelayanan Jalan Raya [7]. Arfandi at.al (2017) meneliti tentang Analisis Tingkat Pelayanan Jalan Andi Djemma Kota Makassar [8]. Marusenge at.al meneliti masalah Pengaruh Hambatan Samping Terhadap Kinerja Pada Ruas Jalan Panjaitan (Kelenteng Ban Hing Kiong) Dengan Menggunakan Metode Mkji 1997 [9]. Funan at.al meneliti tentang Studi Kinerja Jalan Akibat Hambatan Samping Di Jalan Timor Raya Depan Pasar Oesao Kabupaten Kupang [10]

Tujuan dari penelitian ini adalah mengetahui arus lalu litas puncak pada ruas jalan Veteran Selatan serta mengetahui kelas hambatan samping pada ruas jalan Veteran Selatan.

\section{METODOLOGi PENELITIAN}

\section{Tahapan Penelitian}

Secara umum penelitian ini dilakukan melalui beberapa tahapan kerja seperti terlihat dalam gambar 1.

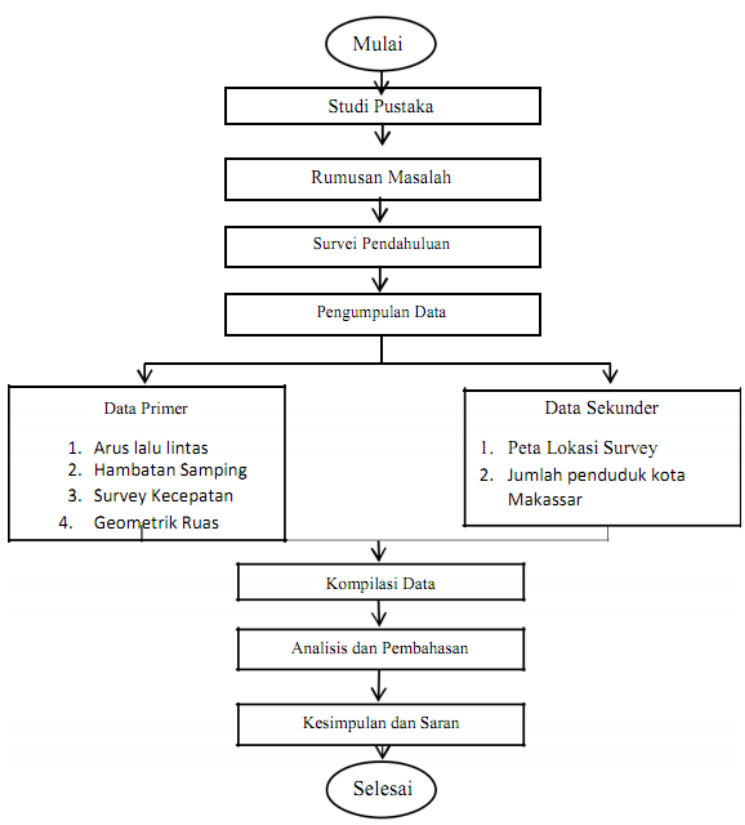

Gambar 1. Tahapan penelitian

\section{Lokasi penelitian}

Penelitian dilakukan di ruas jalan Veteran SelatanKota Makassar,yang di tinjau 200 meter mulai dari jalan Mongisidi sampai jalan Rappocini Raya. Lokasi penelitian seperti pada gambar 2. Spesifikasi ruas jalan sebagai berikut :

- Panjang jalan : 200 m (untuk survei hambatan samping)

- Lebar jalan : 4 m (1 jalur)

- Tipe jalan Empat lajur dua arah terbagi (4/2 D)

Adapun waktu survei dilakukan selama 3 kali dalam seminggu yaitu hari senin, rabu dan saptu dengan pembagian waktu dalam 1 hari dibagi menjadi 3 bagian yaitu jam 06.00-08.00 mewakili waktu pagi jam 11.00-13.00 mewakili waktu siang dan jam 16.00-18.00 mewakili waktu sore

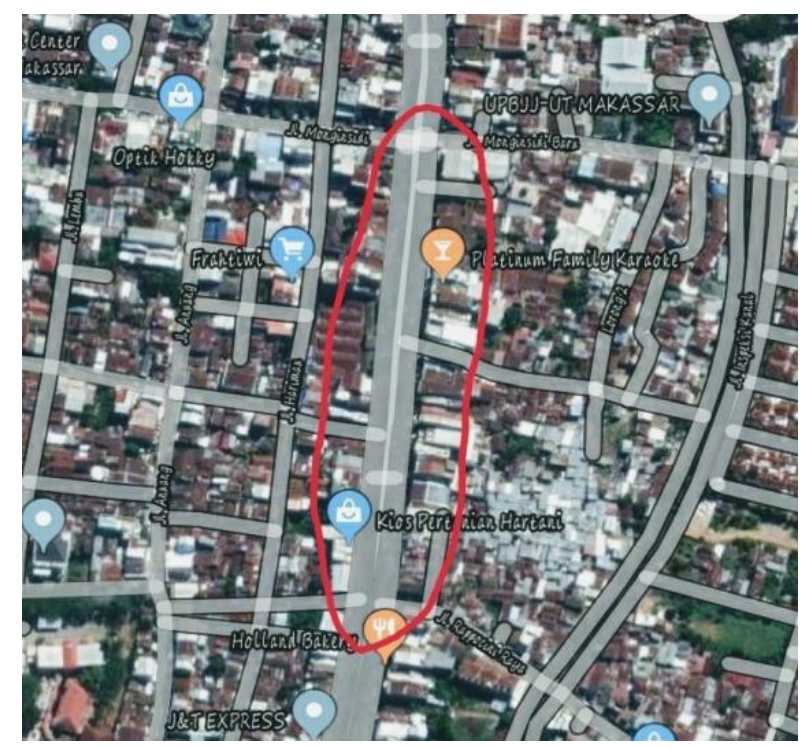




\section{Gambar 2. Lokasi penelitian}

\section{Survei dan pengumpulan data}

a. Survei pendahuluan

Pada tahap ini dilakukan survei ke lokasi yang akan dijadikan sebagai objek penelitian yang dimaksudkan untuk mengetahui apakah lokasi tersebut layak dijadikan sebagai objek penelitian survei pendahuluan ini juga untuk menentukan ruang lingkup pembahasan dan pembatasan masalah yang akan dibahas identifikasi data yang dibutuhkan teknik/cara pengumpulan data termasuk waktu pelaksanaan survey survei pendahuluan ini juga ditunjang dengan studi literatur dari berbagai sumber dan rujukan beberapa studi terdahulu yang berkaitan dengan penelitian ini.

\section{b. Pengumpulan data}

Jenis data yang digunakan dalam penulisan ini adalah data primer atau data inti/pokok dan data sekunder atau data pendukung Data primer adalah data yang diambil langsung di lokasi survei berupa data arus lalu lintas data hambatan samping data geometric jalan serta data survei kecepatan Sedangkan untuk pengumpulan data sekunder mencakup peta lokasi survei dan jumlah penduduk kota Makassar.

Pengambilan data primer dilakukan selama 3 hari dan data yang dikumpulkan yaitu data arus lalu lintas dengan cara mencatat jenis-jenis kendaraan yang melintas seperti kendaraan ringan kendaraan berat sepeda motor dan kendaraan tidak bermotor dan jumlahnya di ruas jalan yang diamati dalam satuan kend/jam dengan interval waktu survei yang digunakan berdasarkan faktor variasi tingkat lalu lintas per $15 \mathrm{mnt}$ dalam satu jam ditetapkan berdasarkan perbandingan antara volume lalu lintas dalam 1 jam dengan empat kali volume lalu lintas per $15 \mathrm{mnt}$ dan setelah diketahui jenis dan jumlah kendaraan yang melintas tersebut nilai ekivalensi mobil penumpang bisa diperoleh dari tabel 1 untuk mengubah satuan (kend/jam menjadi smp/jam Selanjutnya data yang dikumpulkan yaitu data hambatan samping yang dilakukan dengan cara mencatat jumlah kendaraan yang berhenti atau parkir kendaraan yang keluar masuk pada samping jalan pejalan kaki atau penyebrang jalan di sepanjang ruas jalan Veteran Selatan Selanjutnya data geometrik jalan untuk mengetahui lebar jalan dan lebar bahu jalan yang akan digunakan untuk menghitung kapasitas jalan pada persamaan 2 elanjutnya yaitu survei kecepatan untuk mengetahui kecepatan rata-rata kendaraan ringan survei ini dilakukan dengan cara pengamatan langsung Kecepatan kendaraan dihitung dengan melewati dua titik yang telah ditentukan titik awal dimulai dari STA \pm 0 dan titik akhir STA \pm 200 survei dilakukan etiap lima belas mnt dan rata-rata kecepatan diambil untuk periode per jam.

Data sekunder yang diperlukan adalah Peta lokasi survei dan juga jumlah penduduk kota Makassar.

\section{Pos pengamatan}

Untuk mengumpulkan data arus lalu lintas data hambatan samping, serta kecepatan rata-rata kendaraan ringan diperlukan pos pengamatan guna mempermudah pencatatan data tersebut Adapun pos-pos yang dimaksudkan antara :

\section{a. Pos pertama (survei arus lalu lintas)}

Pada pos survei arus lalu lintas yang di survei adalah jumlah kendaraan yang tergolong dalam empat golongan kendaraan berdasarkan MKJI 1997 Yang dimana MKJI membagi menjadi Kendaraan berat truk dan bus kendaran ringan mobil penumpang, mini bus, pick-up, truk kecil, dan jeep dan sepeda motor termasuk kendaraan bermotor beroda tiga. Pos survei arus lalu lintas terdiri atas 1 pos yaitu letaknya pada sta $0+000$ Pada setiap pos diperlukan 2 surveior dan tugas surveior pertama yaitu men survei kendaraan ringan dan berat dan surveior kedua men survei kendaraan bermotor dan menggunakan hand counter.

\section{b. Pos kedua (Hambatan Samping)}

Pada pos ini yang akan disurvei adalah hambatan samping yang berdasarkan MKJI terbagi atas empat yaitu pejalan kaki kendaraan parkir atau berhenti kendaraan masuk atau keluar bahu jalan serta kendaraan lambat Pos survei hambatan samping terbagi atas 2 pos untuk 1 jalur jalur pos pertama letaknya pada sta $0+000$ dan jumlah surveior pada pos ini sebanyak dua surveior yang akan melakukan survei hambatan samping sepanjang $200 \mathrm{~m}$ dari sta $0+000$ sta $0+100$ selanjutnya pos kedua pada sta $100+200$ dan jumlah surveior pada pos ini sebanyak dua surveior yang akan mensurvei hambatan samping sepanjang $200 \mathrm{~m}$ dari sta $0+000$ sta $0+200$ pembagian pos ini berlaku untuk satu jalur dan berdasarkan pembagian surveior terdapat masingmasing 2 surveior di setiap pos yang tugasnya sama yaitu surveior pertama yaitu men survei pejalan kaki dan kendaraan parkir atau berhenti dan surveior kedua men survei yang keluar masuk jalan dan kendaraan lambat berdasarkan MKJI yang tergolong dalam kendaraan lambat yaitu kendaraan tak bermotor (seperti gerobak, sepeda) dan menggunakan alat hand counter Pada survei hambatan samping dilakukan survei keseluruhan bersamaan dengan survei arus lalu lintas dan pada hari selanjutnya dilakukan survei hanya pada saat arus puncak saja. 


\section{c. Pos ketiga ( survei kecepatan)}

Pada pos ini yang akan di survei adalah kecepatan aktual rata-rata kendaraan ringan Pada pos survei kecepatan terdiri atas 1 pos, yang

letaknya pada sta $0+100$, yang akan di survei dilapangan adalah waktu

tempuh kendaraan ringan dalam 100 meter dan jenis kendaraan yang di survei yaitu kendaraan ringan karena lebih mewakili, dipilih kendaraan ringan saat survei kecepatan kendaraan karena kendaraan ringan yang

mewakili populasi kendaraan Di MKJI digunakan istilah V $\mathrm{LV}_{\mathrm{V}}$ tetapi data pengamatan yang lebih mewakili diambil dari banyak kendaraan ringan yang dirata-ratakan kecepatannya sehingga di MKJI dikatakan kecepatan rata-rata kendaraan ringan, maka diambil kendaraan ringan untuk survei kecepatan. Pada pos survei kecepatan di perlukan hanya satu pos yaitu pada sta

$0+100$ dan diperlukan satu surveior dan cara surveinya, surveior menggunakan handycam untuk merekam kendaraan pada saat kendaraan hendak melewati Sta $0+000$ surveior mulai merekam sampai kendaraan tersebut melewati Sta $0+100$ surveior akan melihat waktu pada saat kendaraan masuk pada sta $0+000$ sampai melewati sta $0+100$ setelah itu surveior akan melihat selisih waktu tersebut dan mencatat waktunya Dan banyak kendaraan yang di survei adalah 2 kendaraan ringan dalam $15 \mathrm{mnt}$.

\section{ANALISIS DAN PEMBAHASAN}

\section{Arus Lalu Lintas}

Berdasarkan data observasi, maka arus lalu lintas dapat dihitung dengan menyesuaikan setiap jenis kendaraan ke dalam satuan mobil penumpang pada setiap $15 \mathrm{mnt}$. hasil analisis seperti pada gambar 3.

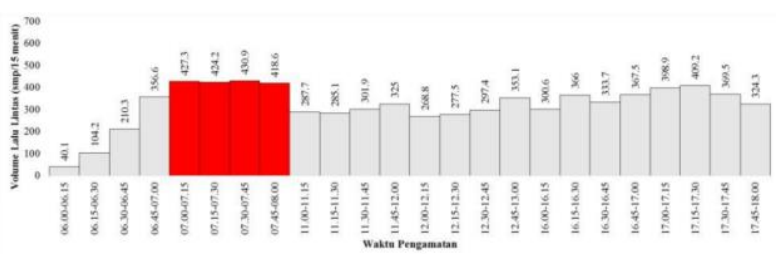

Gambar 3. Arus puncak pada hari senin

Dari gambar 3, dapat diketahui volume lalu lintas tertinggi terjadi dari jam 07.00 sampai jam 08.00. Dimana volume lalu lintas pada jam :

- 07.00-07.15 sebanyak $427.3 \mathrm{smp} / 15 \mathrm{mnt}$,

- 07.15-07.30 sebanyak $424.2 \mathrm{smp} / 15 \mathrm{mnt}$,

- 07.30-07.45 sebanyak $430.9 \mathrm{smp} / 15 \mathrm{mnt}$,

- 07.45-08.00 sebanyak $418.6 \mathrm{smp} / 15 \mathrm{mnt}$.
Sehingga hasil analisis arus puncak pada hari senin diperoleh 1701 smp/jam.

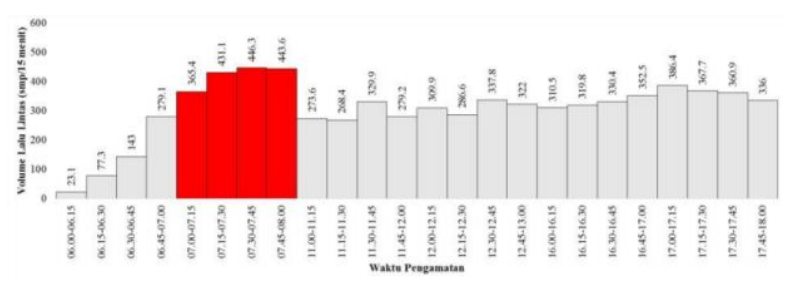

Gambar 4. Arus puncak pada hari rabu

Gambar 4 memperlihatkan volume lalu lintas tertinggi terjadi dari jam 07.00 sampai jam 08.00. Dimana volume lalu lintas pada:

- 07.00-07.15 sebanyak $365.4 \mathrm{smp} / 15 \mathrm{mnt}$,

- 07.15-07.30 sebanyak $431.1 \mathrm{smp} / 15 \mathrm{mnt}$,

- 07.30-07.45 sebanyak $446.3 \mathrm{smp} / 15 \mathrm{mnt}$,

- 07.45-08.00 sebanyak $443.6 \mathrm{smp} / 15 \mathrm{mnt}$.

Sehingga hasil analisis arus puncak pada hari rabu diperoleh 1686.4 smp/jam.

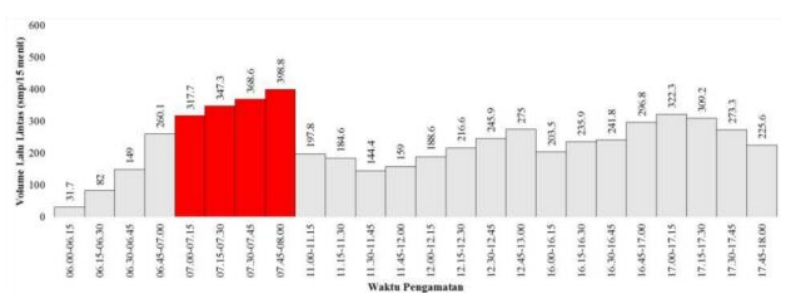

Gambar 5. Arus puncak pada hari sabtu.

Dari gambar 5, dapat dilihat volume lalu lintas tertinggi terjadi dari jam 07.00 sampai jam 08.00. Dimana volume lalu lintas pada jam

- 07.00-07.15 sebanyak $317.7 \mathrm{smp} / 15 \mathrm{mnt}$,

- 07.15-07.30 sebanyak $347.3 \mathrm{smp} / 15 \mathrm{mnt}$,

- 07.30-07.45 sebanyak $368.6 \mathrm{smp} / 15 \mathrm{mnt}$,dan

- 07.45-08.00 sebanyak $398.8 \mathrm{smp} / 15 \mathrm{mnt}$.

Sehingga hasil analisis arus puncak pada hari saptu diperoleh 1432.4 smp/jam.

\section{Hambatan Samping}

Jumlah hambatan samping pada ruas jalan Veteran Selatan yang di tinjau 200 meter dari simpang jalan Mongisidi sampai simpang Rapocini Raya terdapat pada gambar 6 .

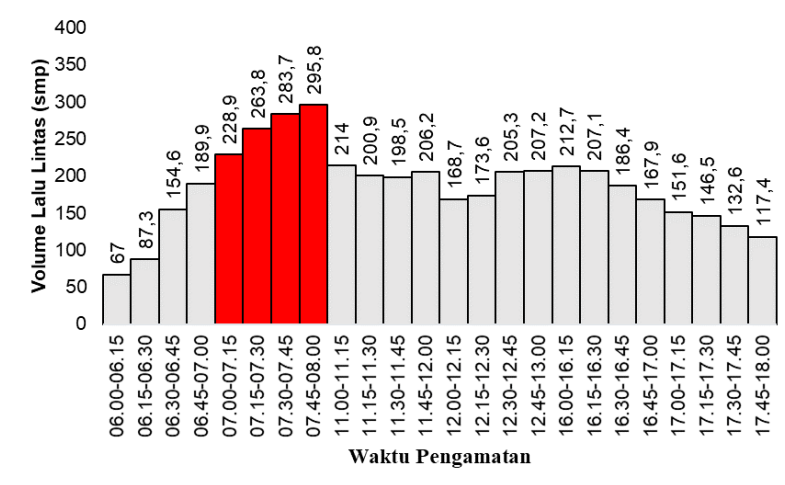


Gambar 7. Hambatan samping pada hari senin Jumlah berbobot kejadian $200 \mathrm{~m}$ per satu jam $=228.9+263.8+283.7+295.8=1072.2$

Dari gambar 7, dapat dilihat arus lalu lintas tertinggi terjadi dari jam 07.00 sampai jam 08.00. Dimana arus lalu lintas pada jam

- 07.00-07.15 sebanyak $228.9 \mathrm{smp} / 15 \mathrm{mnt}$,

- 07.15-07.30 sebanyak $263.8 \mathrm{smp} / 15 \mathrm{mnt}$,

- 07.30-07.45 sebanyak $283.7 \mathrm{smp} / 15 \mathrm{mnt}$, dan

- 07.45-08.00 sebanyak $295.8 \mathrm{smp} / 15 \mathrm{mnt}$.

Sehingga hasil analisis hambatan samping pada hari senin diperoleh 1072.2.

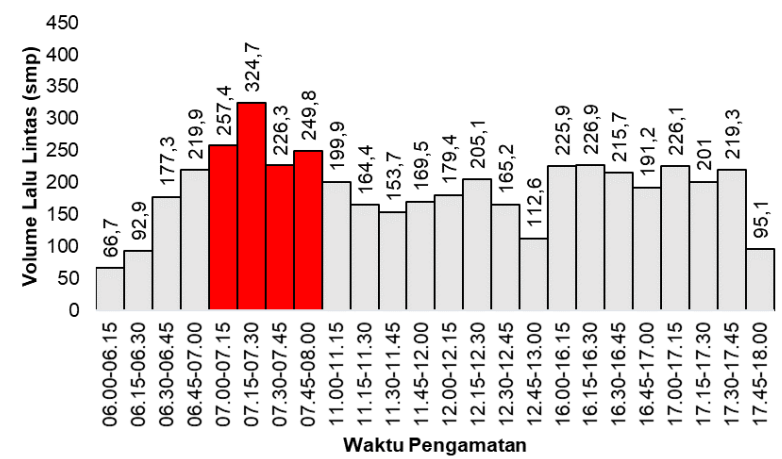

Gambar 7. Hambatan samping pada hari rabu

Jumlah berbobot kejadian $200 \mathrm{~m}$ per satu jam $=257.4+324.7+226.3+249.8=1058.2$

Dari gambar grafik analisis hambatan samping pada hari rabu di atas dapat dilihat arus lalu lintas tertinggi terjadi dari jam 07.00 sampai jam 08.00. Dimana arus lalu lintas pada jam

- 07.00-07.15 sebanyak $257.4 \mathrm{smp} / 15 \mathrm{mnt}$,

- 07.15-07.30 sebanyak $324.7 \mathrm{smp} / 15 \mathrm{mnt}$,

- 07.30-07.45 sebanyak $226.3 \mathrm{smp} / 15 \mathrm{mnt}$, dan

- 07.45-08.00 sebanyak $249.8 \mathrm{smp} / 15 \mathrm{mnt}$.

Sehingga hasil analisis hambatan samping pada hari senin diperoleh 1058.2.

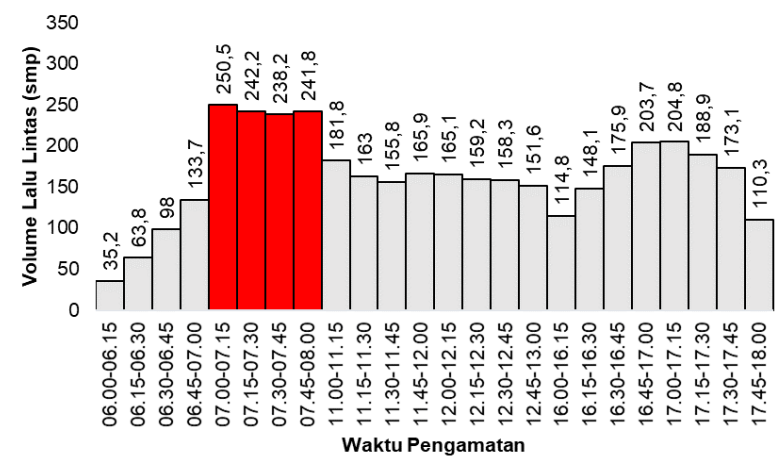

Gambar 8. Hambatan samping pada hari sabtu

Jumlah berbobot kejadian $200 \mathrm{~m}$ per satu jam = $250.5+242.2+238.2+241.8=972.2$.
Dari gambar 8, dapat dilihat arus lalu lintas tertinggi terjadi dari jam 07.00 sampai jam 08.00. Dimana arus lalu lintas pada jam

- 07.00-07.15 sebanyak $250.5 \mathrm{smp} / 15 \mathrm{mnt}$,

- 07.15-07.30 sebanyak $242.2 \mathrm{smp} / 15 \mathrm{mnt}$,

- 07.30-07.45 sebanyak $238.2 \mathrm{smp} / 15 \mathrm{mnt}$,

- 07.45-08.00 sebanyak $241.8 \mathrm{smp} / 15 \mathrm{mnt}$.

Sehingga hasil analisis hambatan samping pada hari senin diperoleh 972.7 .

\section{Pengaruh Hambatan Samping Terhadap Arus Lalu Lintas}

Analisis pengaruh hambatan samping terhadap arus lalu lintas dapat dilihat dari grafik hubungan antara hambatan samping dan arus lalu lintas sebagai berikut :

a. Hubungan antara hambatan samping dan arus lalu lintas hari senin

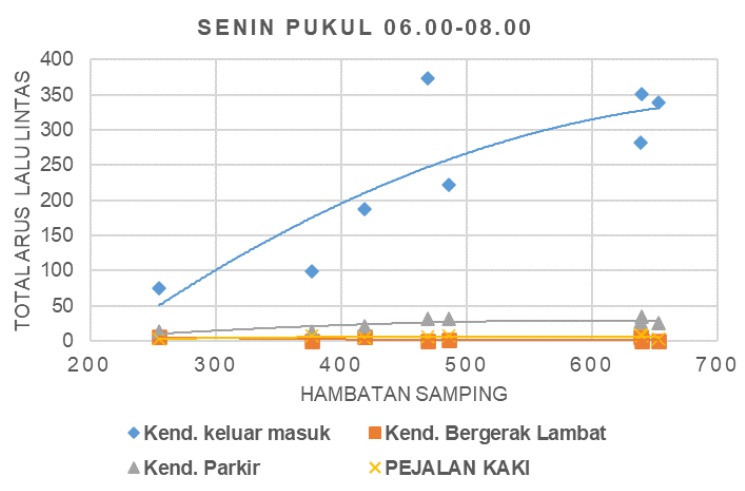

Gambar 9. Hambatan Samping terhadap Arus Lalu Lintas

Dari grafik di atas diketahui hubungan hambatan samping terhadap arus lalu lintas waktu pagi pada pukul 06.00-08.00 yang dapat dilihat dari persamaan yaitu

- untuk kendaraan keluar masuk $y=-0.0012 x^{2}+1.7552 x-321.49$ dengan $R^{2}=0.7057$

- untuk kendaraan bergerak lambat $y=5 E-05 x^{2}-0.052 x+15.755$ dengan $R^{2}=0.1905$,

- untuk kendaraan parkir $y=-0.0002 x^{2}+0.185 x-7.023$ dengan $\mathrm{R}^{2}=0.66$, dan

- untuk pejalan kaki $y=-4 \mathrm{E}-05 \mathrm{x}^{2}+0.0464 \mathrm{x}-5.789$ dengan $\mathrm{R}^{2}=0.2313$. 


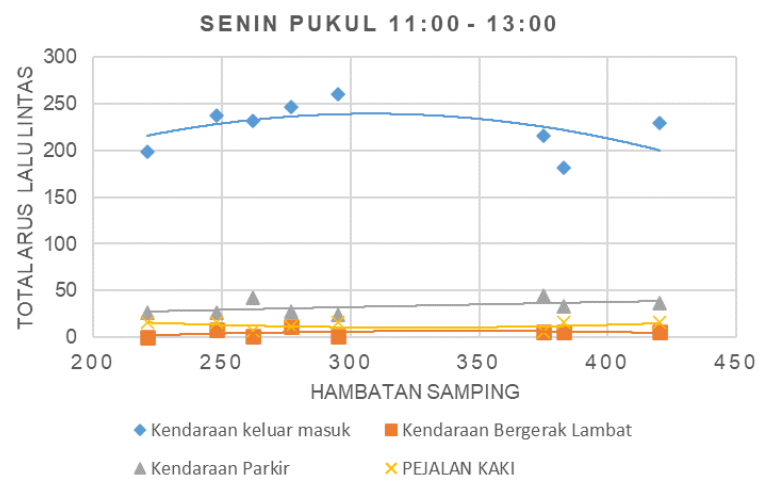

Gambar 10. Hambatan Samping terhadap Arus Lalu Lintas.

Dari gambar 10, dapat diketahui hubungan hambatan samping terhadap arus lalu lintas waktu siang pada pukul 11.00-13.00 yang dapat dilihat dari persamaan yaitu

- untuk kendaraan keluar masuk $y=-0.0031 x^{2}+1.9049 x-54.237$ dengan $\mathrm{R}^{2}=0.2352$,

- untuk kendaraan bergerak lambat $y=-0.0003 x 2+0.22 x-30.508$ dengan $\mathrm{R}^{2}=0.14$,

- untuk kendaraan parkir $y=-4 E-05 x 2+0.0785 x+12.202$ dengan $\mathrm{R}^{2}=0.2749$, dan

- untuk pejalan kaki $y=0.0005 x^{2}-0.3196 x+62.579$ dengan $R^{2}=0.1563$.

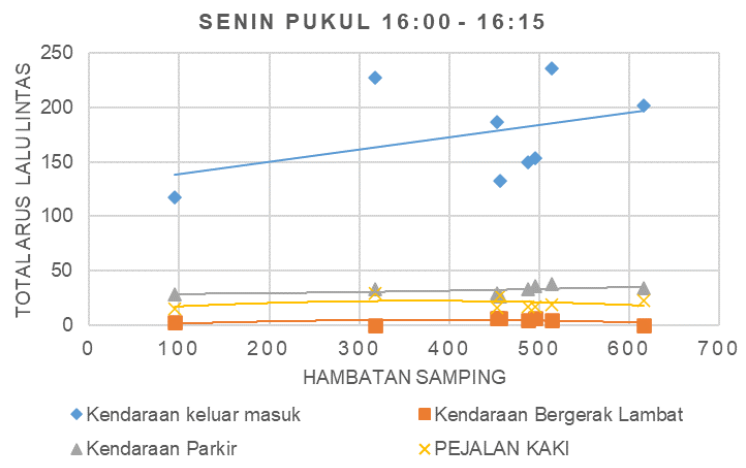

Gambar 11. Hambatan Samping terhadap Arus Lalu Lintas.

Dari 11, dapat diketahui hubungan hambatan samping terhadap arus lalu lintas waktu sore pada pukul 16.00-18.00 yang dapat dilihat dari persamaan yaitu

- untuk kendaraan keluar masuk $y=0.1133 x+127.09$ dengan $\mathrm{R}^{2}=0.1652$

- untuk kendaraan bergerak lambat $y=-5 E-05 x 2+0.0343 x-1.8817$ dengan $\mathrm{R}^{2}=0.2491$,
- untuk kendaraan parkir $y=1 E-05 x 2+0.0036 x+27.888$ dengan $\mathrm{R}^{2}=0.2365$, dan

- untuk pejalan kaki $y=-7 E-05 x 2+0.0524 x+12.447$ dengan $\mathrm{R}^{2}=0.1337$.

b. Hubungan antara hambatan samping dan arus lalu lintas hari rabu

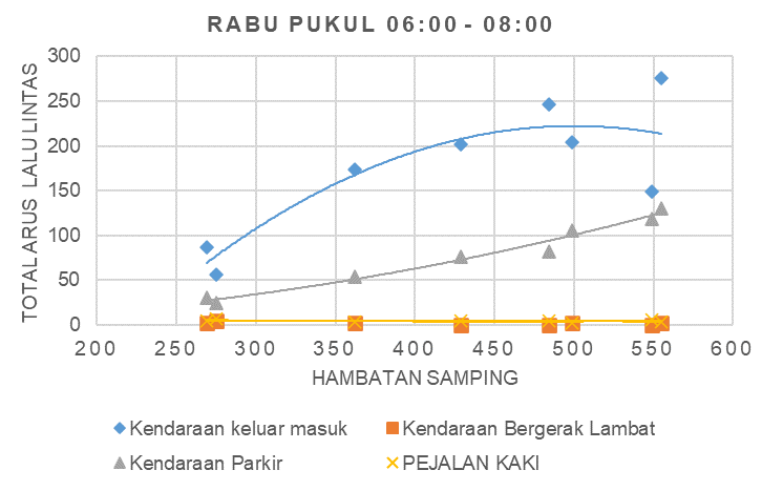

Gambar 12. Hambatan Samping terhadap Arus Lalu Lintas.

Dari gambar 12, dapat diketahui hubungan hambatan samping terhadap arus lalu lintas waktu pagi pada pukul 06.00-08.00 yang dapat dilihat dari persamaan yaitu :

- Kendaraan keluar masuk $y=-0.0029 x 2+2.867 x-494.48$ dengan $\mathrm{R}^{2}=0.7441$,

- Kendaraan bergerak lambat $y=1.667 \ln (x)+14.415$ dengan $R^{2}=0.0835$,

- Kendaraan parkir : $y=0.0005 x 2-0.0322 x+2.9638$ dengan $R^{2}=0.9765$, dan

- Pejalan kaki : $y=5 E-05 x-0.041 x+13.103$ dengan $\mathrm{R}^{2}=0.1259$

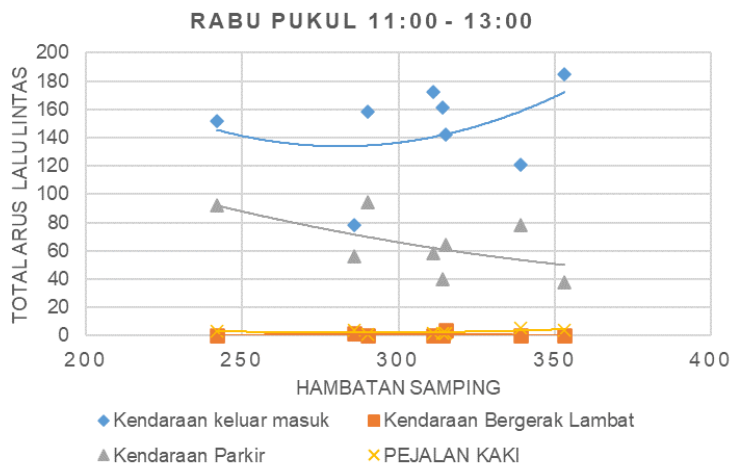

Gambar 13. Hambatan Samping terhadap Arus Lalu Lintas. 
Dari gambar 13 diketahui hubungan hambatan samping terhadap arus lalu lintas waktu siang pada pukul 11.00-13.00 yang dapat dilihat dari persamaan yaitu

- untuk kendaraan keluar masuk $\mathrm{y}=0.0075 \mathrm{x} 2-4.2004 \mathrm{x}+724.91$ dengan $\mathrm{R}^{2}=0.1501$,

- untuk kendaraan bergerak lambat $y=-0.0004 x 2+0.2456 x-35.253$ dengan $\mathrm{R}^{2}=0.1371$,

- untuk kendaraan parkir $y=-1.1522 x 2-1.1522 x+294.39$ dengan $\mathrm{R}^{2}=0.3682$, dan

- untuk pejalan kaki $y=-0.3152 x 2-0.3152 x+47.225$ dengan $\mathrm{R}^{2}=0.3927$

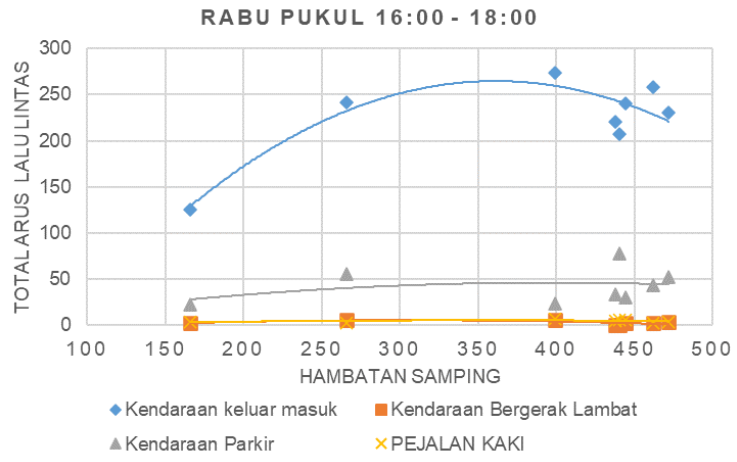

Gambar 14. Hambatan Samping Terhadap Arus Lalu Lintas.

Dari gambar 14 diketahui hubungan hambatan samping terhadap arus lalu lintas waktu sore pada pukul 16.00-18.00 yang dapat dilihat dari persamaan yaitu

- untuk kendaraan keluar masuk $y=-0.0036 x 2+2.5666 x-198.69$ dengan $R^{2}=0.7868$,

- untuk kendaraan bergerak lambat $y=-0.0002 x 2+0.0958 x-9.165$ dengan $R^{2}=0.3083$,

- untuk kendaraan parkir $y=-0.0003 x 2+0.2729 x-7.9024$ dengan $R^{2}=0.1055$, dan

- untuk pejalan kaki $y=-6 E-05 x 2+0.0416 x-2.0634$ dengan $\mathrm{R}^{2}=0.1827$.

c. Grafik hubungan antara hambatan samping dan arus lalu lintas hari sabtu

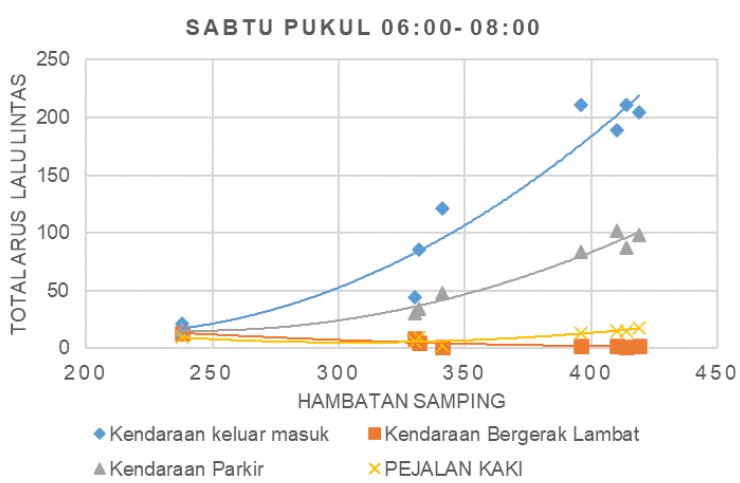

Gambar 15. Hambatan Samping Terhadap Arus Lalu Lintas.

Dari grafik di atas diketahui hubungan hambatan samping terhadap arus lalu lintas waktu pagi pada pukul 06.00-08.00 yang dapat dilihat dari persamaan yaitu

- untuk kendaraan keluar masuk $y=0.0046 x 2-1.8861 x+207.13$ dengan $\mathrm{R}^{2}=0.915$,

- untuk kendaraan bergerak lambat $y=0.0003 x 2-0.2484 x+56.42$ dengan $\mathrm{R}^{2}=0.8365$,

- untuk kendaraan parkir $y=0.0028 x 2-1.3534 x+179.7$ dengan $\mathrm{R}^{2}=0.9647$, dan

- untuk pejalan kaki $y=0.0009 x 2-0.5731 x+92.427$ dengan $\mathrm{R}^{2}=0.8444$

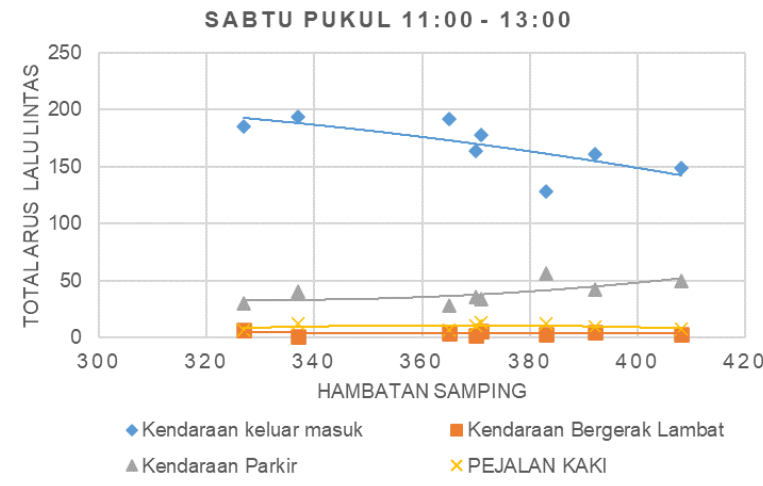

Gambar 16. Hambatan Samping Terhadap Arus Lalu Lintas.

Dari grafik di atas diketahui hubungan hambatan samping terhadap arus lalu lintas waktu siang pada pukul 11.00-13.00 yang dapat dilihat dari persamaan yaitu

- untuk kendaraan keluar masuk $y=-0.0024 x 2+1.1618 x+71.813$ dengan $R^{2}=0.521$,

- untuk kendaraan bergerak lambat $y=0.0004 x 2-0.2904 x+58.859$ dengan $R^{2}=0.04$ 
- untuk kendaraan parkir $y=0.0034 x 2-2.2485 x+407.48$ dengan $\mathrm{R}^{2}=0.4332$, dan

- untuk pejalan kaki $y=-0.0015 x 2+1.1158 x-193.56$ dengan $\mathrm{R}^{2}=0.1988$.

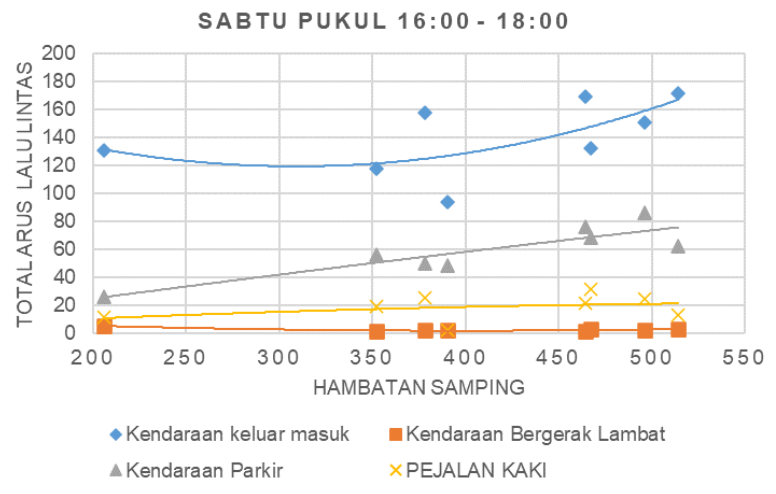

Gambar 17. Hambatan Samping Terhadap Arus Lalu Lintas.

Dari grafik di atas diketahui hubungan hambatan samping terhadap arus lalu lintas waktu sore pada pukul 16.00-18.00 yang dapat dilihat dari persamaan yaitu

- untuk kendaraan keluar masuk

$$
y=0.0011 x 2-0.7018 x+227.77 \text { dengan }
$$

$R^{2}=0.4004$,

- untuk kendaraan bergerak lambat $y=9 E-05 x 2-0.0733 x+16.134$ dengan

$\mathrm{R}^{2}=0.7401$,

- untuk kendaraan parkir $y=-4 E-05 x 2-0.1935 x-12.472$ dengan $R^{2}=0.7739$, dan

- untuk pejalan kaki $y=-6 E-05 x 2+0.0804 x-3.2646$ dengan $\mathrm{R}^{2}=0.1385$

\section{Kapasitas Jalan}

Analisis kapasitas aktual jalan yang digunakan adalah mengacu pada MKJI 1997 dengan menggunakan persamaan sebagai berikut :

$\mathrm{C}=\mathrm{C}_{0} \times \mathrm{FC}_{\mathrm{w}} \times \mathrm{FC}_{\mathrm{SP}} \times \mathrm{FC}_{\mathrm{SF}} \times \mathrm{FC}_{\mathrm{CS}}$

Keterangan :

C = Kapasitas aktual jalan (smp/jam)

Co = 1650 (Kapasitas dasar per lajur (smp/jam)

$\mathrm{FCW}=1,08$ ( faktor penyesuain lebar jalur lalu lintas untuk tipe jalan dua Arah dengan lebar lajur efektif $W c=4 \mathrm{~m}$ )

$\mathrm{FC}_{\mathrm{SP}}=0,985$ Untuk perbandingan (55\%-45\% untuk tipe jalan dua arah)

$\mathrm{FC}_{\text {SF }}=0,84$ (factor penyusaian hambatan samping dengan lebar bahu tipe jalan
4/2 D hambatan samping $\mathrm{VH}=$ Very High)

FCcs $=1,0$ (faktor penyesuain ukuran kota, Kota Makassar berpenduduk 1.469.601 juta jiwa)

C $\quad=1650 \times 1,08 \times 0,985 \times 0,84 \times 1$

$=1474,4 \mathrm{smp} / \mathrm{jam}$

\section{Kinerja Jalan}

a. Derajat Kejenuhan

Derajat kejenuhan dapat dihitung dengan menggunakan persamaan :

$\mathrm{DS}=\mathrm{Q} / \mathrm{C}$

Keterangan :

DS = Derajat kejenuhan

Qsenin = $1701 \mathrm{smp} / \mathrm{jam}$ Arus puncak rata-rata.

Qrabu $=1686.4$ smp/jam Arus puncak rata-rata.

Qsabtu $=1432.4 \mathrm{smp} / \mathrm{jam}$ Arus puncak rata-rata.

C = 1474,4 smp/jam, yaitu kapasitas aktual jalan.

Derajat kejenuhan (DS) pada kondisi arus puncak sehari-hari.

DSsenin $=\frac{1701}{1474,4}=1,15$

DS rabu $=\frac{1686,4}{1474,4}=1,14$

DS sabtu $=\frac{1432,4}{1474,4}=0,97$

Nilai derajat kejenuhan yang lebih besar dari pada 0,75 menunjukkan kondisi arus lalu lintas macet.

b. Kecepatan arus bebas

Dalam menentukan kecepatan arus bebas, maka digunakan persamaan

$F V=\left(F V_{0}+F V_{w}\right) \times F F V_{S F} \times F F V_{C S}$

Dimana :

FV = kecepatan arus bebas kendaraan ringan pada kondisi lapangan (km/jam)

FVo $=(57 \mathrm{~km} /$ jam $)$, kecepatan arus bebas dasar kendaraan ringan

$\mathrm{FVw}=(4 \mathrm{~km} / \mathrm{jam})$, faktor penyesuaian kecepatan arus bebas untuk lebar lalurlalu lintas

$F F V_{S F}=(0,84)$,faktor penyesuaian hambatan samping

FFV $\mathrm{CS}=(1)$, faktor penyesuaian ukuran kota

Maka diperoleh kecepatan arus bebas : 
$\mathrm{FV} \quad=51,24 \mathrm{~km} / \mathrm{jam}$

\section{Kecepatan rata-rata kendaraan ringan}

Karena derajat kejenuhan yang diperoleh pada hari senin sebesar 1,18 atau lebih besar dari 1 maka kecepatan rata-rata kendaraan ringan tidak dapat ditentukan, kemudian untuk hari rabu nilai yang diperoleh sebesar 0,94 maka nilai kecepatan ratarata kendaraan ringan yaitu $60 \mathrm{~km} / \mathrm{jam}$ dan untuk hari sabtu nilai yang diperoleh sebesar 0,89 maka nilai kecepatan rata-rata kendaraan ringan yaitu 60 $\mathrm{km} / \mathrm{jam}$

\section{Pembahasan}

Dari hasil survey didapatkan nilai sebagai berikut :

\section{Arus lalu lintas}

Arus lalu lintas puncak rata-rata diperoleh dari arus lalu lintas puncak selama 3 hari pengamatan yaitu pada hari senin nilai yang di dapatkan adalah 1701 smp/jam terjadi pada pukul 07.00-08.00, pada hari rabu nilai yang didapatkan adalah 1686,4 smp/jam arus puncak ini terjadi pada 07.00-08.00, pada hari sabtu nilai yang didapatkan 1432,4 smp/jam arus puncak ini terjadi pada 07.00-08.00.

\section{Hambatan Samping}

Nilai hambatan samping yang diperoleh pada hari senin adalah 1072 smp/jam pada pukul 07.0008.00 pada hari rabu nilai yang diperoleh adalah $1058 \mathrm{smp} / \mathrm{jam}$ pada pukul 07.00-08.00 kemudian pada hari sabtu nilai yang didapatkan adalah 972,12 smp/jam pada pukul 07.00-08.00. Didapatkan nilai rata-rata hambatan samping selama 3 hari adalah 1034,13 smp/jam kejadian per $200 \mathrm{~m}$ per jam ini tergolong dalam kelas hambatan samping sangat tinggi (very high).

\section{KESIMPULAN}

1. Berdasarkan analisa jalan perkotaan mengunakan pedoman MKJI 1997, kondisi arus lalulintas di ruas jalan Veteran Selatan cukup tinggi di jam-jam tertentu, dan pada penelitian yang saya lakukan selama 3 hari yaitu hari senin, rabu, dan sabtu arus pucak terjadi pada pagi hari mulai dari pukul 07.00-08.00 dikarena tingginya aktivitas masyarakat di ruas jalan Veteran Selatan pada jam tersebut

2. Kelas hambatan samping (SFC) pada ruas jalan Veteran Selatan sangat tinggi disebabkan banyaknya pemilik kendaraan yang parkir di sepanjang jalan tersebut, khususnya kendaraan ringan yang mengunakan badan jalan untuk parkir.
Kondisi ini di perburuk karena di sepanjang jalan Veteran Selatan banyak ada banyak toko yang memiliki lahan parker

\section{DAFTAR PUSTAKA}

[1] E. K. Morlok, 1991, Pengantar Teknik dan Perencanaan Transportasi. Jakarta: Erlangga.

[2] Direktorat Bina Marga, 1997, "Manual Kapasitas Jalan Indonesia (MKJI)," Jakarta: Departemen Pekerjaan Umum.

[3] Henry. S. M. Pirade, I. . S. Kato, S. Bestari, dan R. Rachman, 2019, "Pengaruh Hambatan Samping Terhadap Kinerja Ruas Jalan Antang Raya Kota Makassar," Paulus Civ. Eng. J., vol. 1, no. 1, Art. no. 1.

[4] O. C. Tamin, 2000, Perencanaan dan Pemodelan Transportasi, 2 ed. Bandung: Institut Teknologi Bandung.

[5] J. Khisty C. dan B. K. Lall, 2005, Dasar Dasar Rekayasa Transportasi, 3 ed., vol. 1. Jakarta: Erlangga.

[6] G. K. Febry, R. Rachman, dan L. E. Radjawane, 2020, "Kinerja Simpang Bersinyal Jalan Abdullah Daeng Sirua - Batua Raya Taman Makam Pahlawan Kota Makassar," Paulus Civ. Eng. J. Ojsukipaulusacid, vol. 2, no. 1 , hlm. $23-30$.

[7] S. Kurniawan, 2016, "Analisa Hambatan Samping Terhadap Tingkat Pelayanan Jalan Raya," J. TAPAK, vol. 6, no. 1, Art. no. 1.

[8] A. Arfandi, N. Pertiwi, dan Rahmatan, 2017, "Analisis Tingkat Pelayanan Jalan Andi Djemma Kota Makassar," J. Inov. Dan Pelayanan Publik Makassar, vol. 1, no. 1, Art. no. 1.

[9] Gallant. S. Marunsenge, J. A. Timboeleng, dan L. Elisabeth, 2015, "Pengaruh Hambatan Samping Terhadap Kinerja Pada Ruas Jalan Panjaitan (Kelenteng Ban Hing Kiong) Dengan Menggunakan Metode Mkji 1997," J. Sipil Statik, vol. 3, no. 8, hlm. 571-582.

[10] G. A. Funan, R. Cornelis, dan E. Hunggurami, 2014, "Studi Kinerja Jalan Akibat Hambatan Samping Di Jalan Timor Raya Depan Pasar Oesao Kabupaten Kupang," J. Tek. Sipil Dan Teknol., vol. III, no. 1, hlm. 1-12. 